\title{
BIOGAS PROCTION FROM ANAEROBIC CO-DIGESTION OF COW DUNG AND ORGANIC WASTES (NAPIER PAK CHONG I AND FOOD WASTE) IN THAILAND: TEMPERATURE EFFECT ON BIOGAS PRODUCT
}

\author{
${ }^{1}$ Lertluck Saitawee, ${ }^{1}$ KanokornHussaro, ${ }^{2}$ Sombat Teekasap and ${ }^{3}$ Noppadon Cheamsawat \\ ${ }^{1}$ Rattanakosin College for Sustainable Energy and Environment, \\ Rajamangala University of Technology Rattanakosin, \\ PuthamonthonSai 5, Salaya, Puthamonthon, NakhonPathom, 73170, Thailand \\ ${ }^{2}$ Department of Mechanical Engineering, Faculty of Engineering, \\ Eastern Asia University, Thanyaburi, PathumThani, 12110, Thailand \\ ${ }^{3}$ University Technology Office for SMEs, \\ King Mongkut's University of Technology Thonburi, Bangkok, 10140, Thailand
}

Received 2014-02-07; Revised 2014-02-14; Accepted 2014-04-01

\begin{abstract}
Biogas production has been attracting increasing attention as a biofuel of the future because biogas technology not only constitutes a biofuel source, but also can be applied in the various environmental pollutants. Anaerobic digestion of high solid slurries (such as food waste and cow dung) is typically performed in continuously reactor (by force substrate flow) to avoid problems with a thick floating layer or large amounts of sediments. Temperature also seems to have profound influence on the biogas production. The objective of the study was to identify the optimum biogas production for anaerobic co-digestion of cow dung and organic wastes (napierpakchong I and food waste). Influence of temperature (psyhrophilic temperature $25^{\circ} \mathrm{C}$ and thermoplilic temperature $45^{\circ} \mathrm{C}$ ) and active biogas process on single substrate (food waste feed) and co-digestion of cow dung and organic wastes (napierpakchong I and food waste) was used, within the reactor was studies in $1.80 \mathrm{~cm}$ high over a 45 day. Results showed that best digestion was achieved when digested of cow dung, napierpakchong I and food waste) on 1:1:1 and thermoplilic temperature. Maximum biogas production (R4), biogas yield, methane content and \%VS reduction was found that $70 \mathrm{~L} /$ day, $70 \mathrm{~L} / \mathrm{VS}$ feed, 65 and $80 \%$, respectively. The result showed that the biogas production increased progressively withhigher temperature.The increased in biogas production in thermophilic temperature and psyhrophilic temperature could be up 28.01 and $26 \%$, respectively. The biogas yield increased $12.5 \%$ of co-digestion system, which compared to thermophilic temperature and psyhrophilic temperature (R4 and R2). This behavior might be due to the higher degradability. Therefore, temperature of digester can be used effectively as an operating strategy to optimize biogas production.
\end{abstract}

Keywords:Biogas Production, Methane Content, Napierpakchong I, Organics Waste, Cow Dung, Food Waste, Thermoplilic Temperature, Psyhrophilic Temperatureand Anaerobic Co-Digestion

\section{INTRODUCTION}

Thailand is full of suitable areas for agriculture and plantation. Therefore, Thailand's agricultural products are enough for domestic consumption. Moreover, Thailand also has sufficient agricultural products for exportation. Most energy used in Thailand is from oil that is mostly imported from other countries. When

Corresponding Author: KanokornHussaro, Rattanakosin College for Sustainable Energy and Enviroment,

Rajamangala University of Technology Rattanakosin, PuthamonthonSai 5, Salaya, Puthamonthon,

NakhonPathom, 3170,Thailand 
comparing the price of Thai exported agricultural products with the price of imported oil, it is found that exported agricultural products are cheaper than the price of imported oil. As a result, if there is any change of agricultural products by dividing some areas for planting products that is sufficient domestic consumption and some areas for planting some alternative energy plants for domestic consumption, it will be the solution for creating Thailand's balance of trade. Agriculture has the potential for replacing some of the purchased energy in the form of fossil fuels, commercial fertilizer and field produced animal feed with bioenergy and organic fertilizer and animal feed from on-site renewable biomass in order to economically and environmentally sustain it self (Ghaly and Hattab, 2012). Most Thai people live in the capital city and big cities of each region contributing areas of high population density resulting in high level of consumption. Consequently, there is a consecutive problem on large amount of waste and food scrapes leading to the problem of waste and food scrapes management of big cities' municipality. The solution that is mostly used to solve this problem is landfill requiring the areas for processing bringing pollution to residents who live nearby such areas in case of poor management. For Thailand's agricultural development, there is a research and development of Giant King Grass (Napier Pak Chong I) plantation for animal husbandry in the areas of Pak Chong district, NakhonRatchasima province. This kind of grass is grown easily and able to be bred well and rapidly. Cutting can breed it and its tillering stage is generated automatically without new growing. As a result, it can be harvested at least 7 years with the average productivity of 40-80 tons/rai/year.

Energy consumption increases rapidly because of high economic development speed rate of Thailand. Biogas is seen as an important source of energy to meet the electricity demands for small towns and rural areas. Biogas is produced by Anaerobic Digestion (AD) of organic feedstock, the most common being animal wastes and crop residues, dedicated energy crops, domestic food waste and Municipal Solid Waste (MSW); the integrated process included feedstock supply and pretreatment and use of digestate. Biogas consist of 50-70\% Methane $\left(\mathrm{CH}_{4}\right), 25-45 \%$ Carbon Dioxide $\left(\mathrm{CO}_{2}\right), 2-7 \%$ Water $\left(\mathrm{H}_{2} \mathrm{O}\right)$ at $20-40^{\circ} \mathrm{C}, 2-5 \%$ Nitrogen $\left(\mathrm{N}_{2}\right), 0-2 \%$ Oxygen $\left(\mathrm{O}_{2}\right)$ and less than $1 \%$ Hydrogen $\left(\mathrm{H}_{2}\right), 0-1 \%$ Ammonia $\left(\mathrm{NH}_{3}\right)$ and 0-6000 ppm Hydrogen Sulphide $\left(\mathrm{H}_{2} \mathrm{~S}\right)$ (Akbulut, 2012). Anaerobic of manure, alone or in a mixture of manure and others organic wastes, is widely used today. A number of full-scale anaerobic mesophilic and thermophilic digesters for biogas production have been developed in Thailand. Temperature and the type of raw material are two of most important parameters in anaerobic digestion. The anaerobic digestion is, of course strongly affected by the type of raw material and both the methane yield and the possible reduction of the solid content depends on the composition of the waste material (Alvarez and Lidén, 2009).

Anaerobic digestion can be complete at psyhrophilic $\left(10-25^{\circ} \mathrm{C}\right)$, mesophilic $\left(30-40^{\circ} \mathrm{C}\right)$ or thermophilic $\left(50-60^{\circ} \mathrm{C}\right)$ temperature and can occur under hydraulic flow regimes being Batch Reactor (BR), Sequencing Bath Reactor (SBR) or Continuous Flow Reactors (CFR). Continuous flow bioreactors are operated as a Plug Flow Reactor (PFR) or as a Completely Stirred Tank Reactor (CSTR). Both CFR types are operated at constant volume, which means that as substrate is fed into the bioreactor an equivalent and is more prone to biomass washout and bioreactor failure than sequencing bath reactors (Massé et al., 2011). Compared to orther biological treatment process, the advantages of biogas plants are varied; (i) economically attractive investment, (ii) easily operated and safe installation, (iii) production of renewable electricity and heat resulting in a reduction of $\mathrm{CO}_{2}$ emissions (iv) reduction of methane emissions from manure storage, (v) improvement of fertilizing qualities of manure (Akbulut, 2012), (vi) production of usable biogas that is about $60-80 \%$ methane with a fuel value of $17-23.9 \mathrm{MJ} / \mathrm{m}^{3}$, (vii) the digested residue is almost odorless with reduced solids content, (viii) the inorganic nutrients are conserved in the digestion process resulting in the enhancement of the fertilizer value of the digested sludge and (viiii) pathogenic microorganisms such as Salmonella $\mathrm{Sp}$. and Brucella $\mathrm{Sp}$. as well as weed seeds are destroyed during the anaerobic digestion process (Ghaly and Hattab, 2011).

Co-digestion of mixed substrates offers many advantages, including ecological, technology and economic benefits compared to digesting a single substrate (Brown and Li, 2013). According to Brown and Li (2013), digestion of more than one substrate in the same digester, which food waste collected from restaurants, which was found to have a $\mathrm{C} / \mathrm{N}$ ratio of 15 , could be added to balance the $\mathrm{C} / \mathrm{N}$ ratio of yard waste. The final mixture of liquid $\mathrm{AD}$ effluent, yard waste and food waste should have a $\mathrm{C} / \mathrm{N}$ ratio in range 20-30 for optimum microbial performance.

From the problem of big cities regarding large amount of waste and food scraps resulting in agricultural sector, there is the development of grass growing in Pak Chong district. This is the concept of energy research and development by fermenting Napier Pak Chong 1 
(NPC) with food waste scrapes to obtain biogas energy. In this research, biogas was produced first by single digestion of Napier Pak Chong 1 (NPC) and then by codigestion of NPC and food waste and the amount of biogas and methane content produced were compared was obtained from continuous anaerobic digester. A series of experiments were carried out under psyhrophilic $\left(25^{\circ} \mathrm{C}\right)$ and thermophilic $\left(45^{\circ} \mathrm{C}\right)$ condition using continuously tank reactors.

\section{ATERIALS AND METHODS}

\subsection{Materials}

Napier Pakchong I (NPC), food waste and cow dung were used as substrate in this experimental study. Napier pakchong I was collected, during August 2013, fromPakchong, NakhonratchasimaProvice, Thailand. The sampleswerescraped off thefeedlanesandcollected in 5 tonsbucketsandthendroundwith a hammermillto pass through a $5 \mathrm{~mm}$ screenandstored in airtightcontainersuntilused. The samplesweretransportedimmediatelytothe LC Technologies Limited Partnership, Pakkred, Nonthaburi, Thailand. Therewerefilling 1.76 $\mathrm{kg}$ /dayofnapierpakchong I (with 45 daysofage). Cowdungandchickendung (inoculum) werecollectedfrom dairyfarmnearNakhonratchasimaProvice, Thailand $\begin{array}{lll}\text { during } & \text { August } & \text { The }\end{array}$ samplesweretransportedimmediatelytothe LC

\begin{abstract}
Technologies Limited Partnership, Pakkred, Nonthaburi, Thailand andstored in a refrigeratoratapproximately $5{ }^{\circ} \mathrm{C}$. Food waste was obtainedas a homogenizedandsanitizedsuspensionfrom a municipality, whichcollectedfoodresiduesfromrestaurants, hospitals, universitycamteens andsupermarkets. Food waste was colleted, during August 2013 andprovidedby a LC Technologies Limited Partnershipprocessing 0.34 $\mathrm{kg}$ /dayoffoodwaste, byscreeningandgrinding, asfeedstockfor a municipalanaerobicdigester. Food waste was obtainedas a co-substrate forbiowastedigestion was selected due toitssteadyavailability, high nutrientcontentandbiodegradabilityand high methane potential (Satoto et al., 2010). The most important characteristics of three substrates for anaerobic codigestion experiments are presented in Table 1.
\end{abstract}

\subsection{Experimental Method}

The organics wastes were anaerobically digested for the determination of biogas production potential, as shown in Fig. 1. Four different batches of experiments were conducted in the study and all of reactors were operated in parallel. $872 \mathrm{~L}$ continues batch digesters were used in the small scale. In Reactor 1 (R1) contained $100 \%$ of food waste and Reactor 2 (R2) mixture contained 1:1 of napierpakchong I: Food waste, base on Volatile Solids (VS) $30 \%$ of food waste and $70 \%$ of napierpakchong I, respectively, which R1 and R2 were carried out on digestion at psyhrophilic $\left(25^{\circ} \mathrm{C}\right)$ for 45 days.

\section{Co-digestion process}

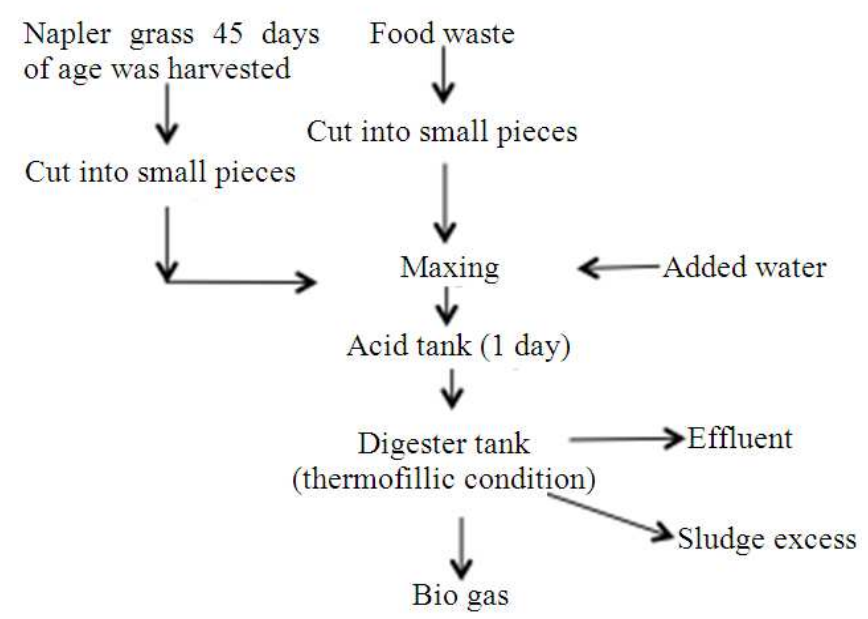

Fig. 1. Biogas production process for co-digestion of organic wastes 


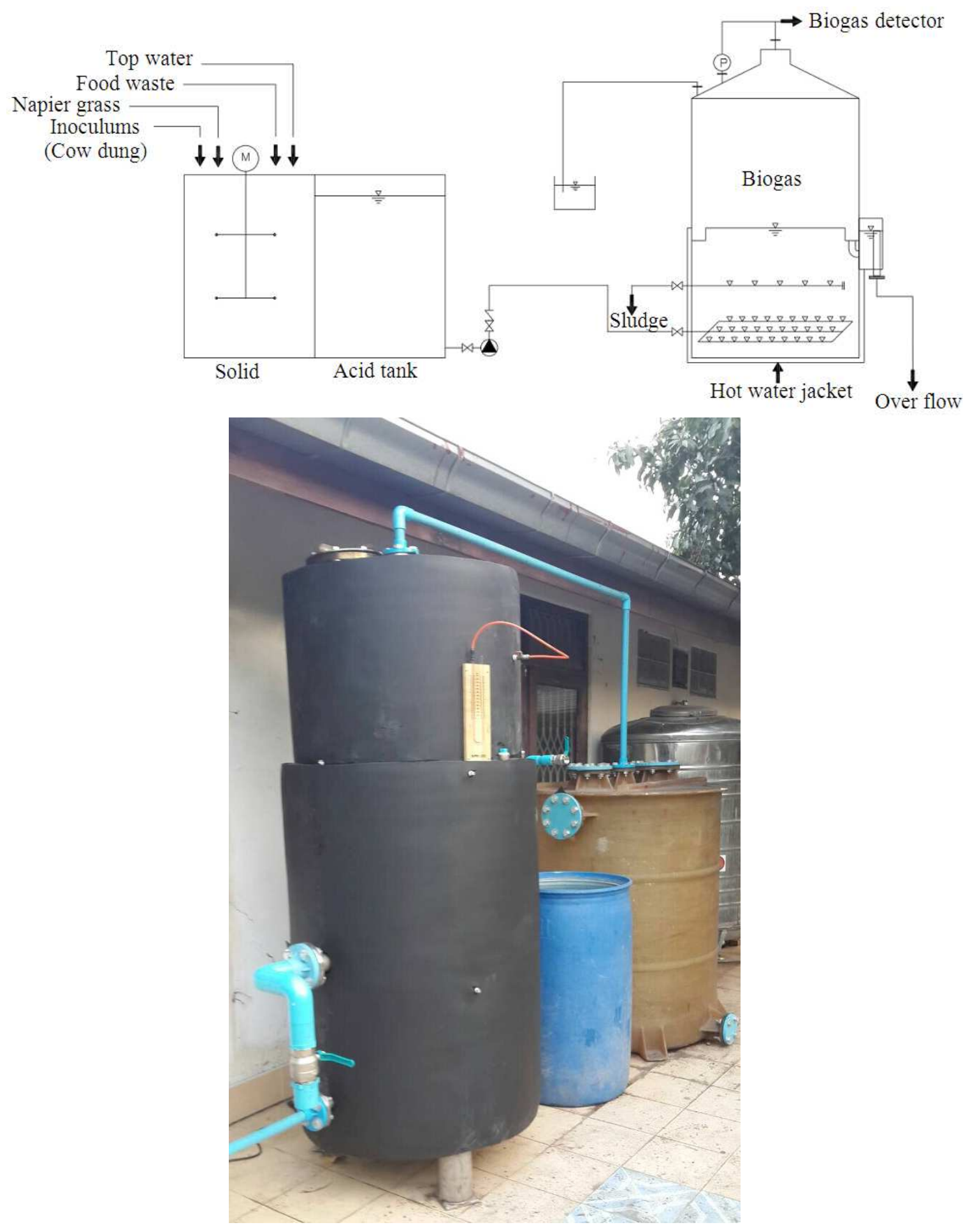

Fig. 2. Experimental set up for biogas production 

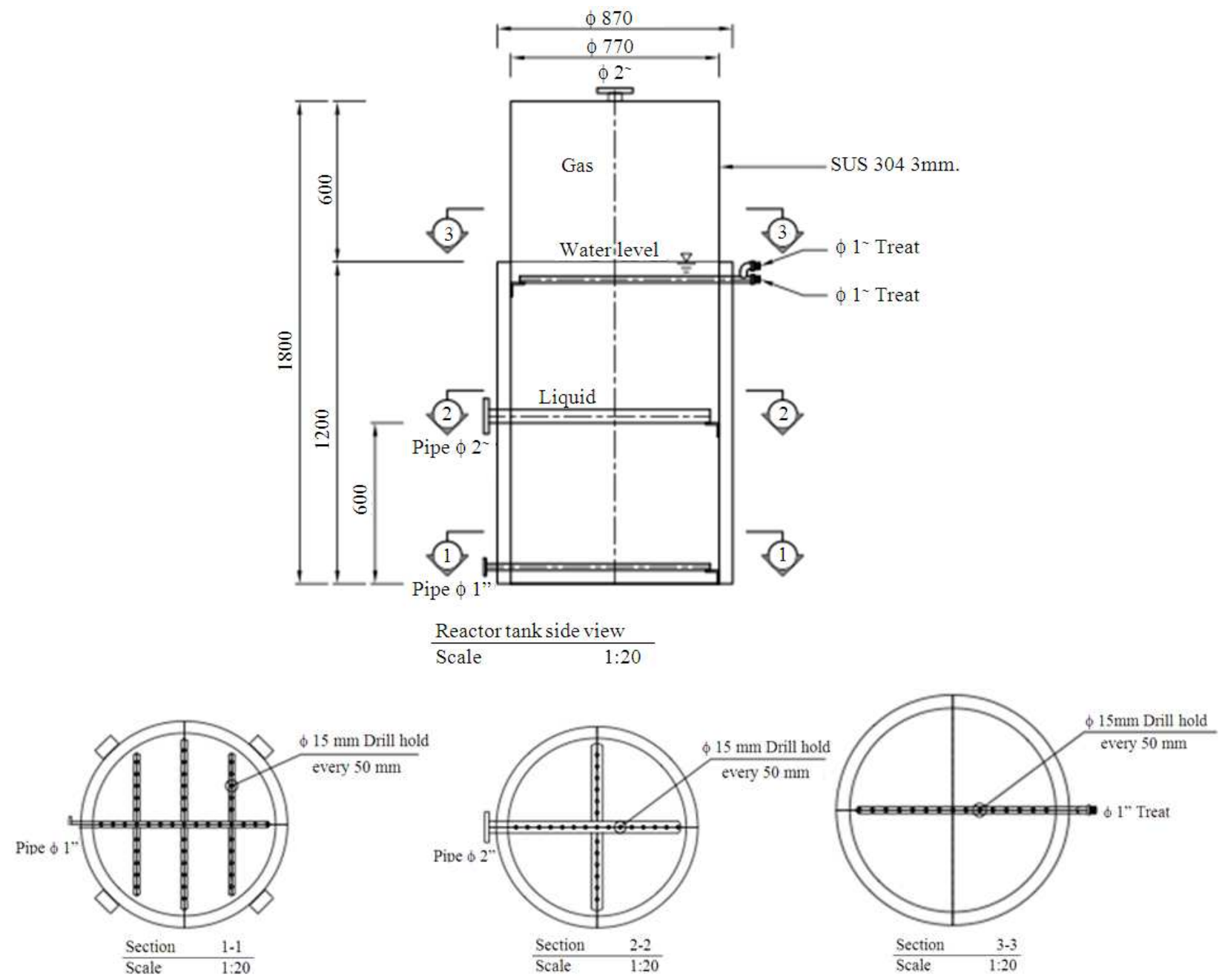

Fig. 3. Size of reactor for biogas production

Table 1. Characteristics of substrate

\begin{tabular}{llll} 
& Substrates & Inoculum & \\
Parameters & -0.0 Cowdung \\
\hline $\mathrm{pH}$ & Napier pakchong I & Food waste & 7.5 \\
$\mathrm{TKN}(\mathrm{mg} / \mathrm{L})$ & 4.5 & 4.27 & 285 \\
$\mathrm{NH}_{3}(\mathrm{mg} / \mathrm{L})$ & 420 & 1,185 & 30.1 \\
Total solids (mg/L) & 38.49 & 42.7 & 588,366 \\
Volatile solids (mg/L) & 629,293 & 176,728 & 11,400 \\
Volatile Suspendedsolids (mg/L) & 68,400 & 158,231 & 7,600 \\
Total phosphorus (mg/L) & 69,300 & 109,210 & 299.33 \\
Suspendedsolids (mg/L) & 88.040 & 546 & 533,116 \\
\hline
\end{tabular}

In reactor $3(\mathrm{R} 3)$ contained $100 \%$ of food waste and reactor 4(R4) mixture contained 1:1 of napierpakchong I: Food waste, base on Volatile Solids (VS) $30 \%$ of food waste and
$70 \%$ of napierpakchong 1 , respectively, which R3 and R4 were carried out on digestion at thermophilic $\left(45^{\circ} \mathrm{C}\right)$ for 45 days. In each digestion, the first day started with water 
about $593 \mathrm{~L}$ and then added $2 \mathrm{~kg}$ day $^{-1}$ of inoculum (cow dung) was used. The TS and VS of the inoculum used were 299.33 and $11,400 \mathrm{mg} \mathrm{L}^{-1}$, respectively. Schematic experimental biogas fermentation set up and digester are presented, as shown in Fig. 2 and 3.

Daily gas production was measured by using water displacement method and corrected for Standard Temperature and Pressure (STP). During the digestion period, the reactors were automatic mixed each day prior to gas measurement to maintain intimate contact between the microorganisms and the substrate. Daily gas production was recorded and corrected for STP and the biogas composition was measured by Portable gas analyzer (BIOGAS 5000). Daily pressure differences were converted into biogas volumes using the following Equation 1 (Hamed and Zhang, 2012):

$$
\mathrm{V}_{\text {Biogas }}=\frac{\text { P. } \mathrm{V}_{\text {haad }} \cdot \mathrm{C}}{\text { R.T }}
$$

Where:

$$
\begin{aligned}
& \mathrm{V}_{\text {Biogas }}=\text { Daily biogas volum }(\mathrm{L}) \text {, } \\
& \mathrm{P} \quad=\text { Absolute pressure difference (mbar), } \\
& \mathrm{V}_{\text {head }}=\text { Volume of the head space }(\mathrm{L}) \text {, } \\
& \mathrm{C}=\text { Molar volume }\left(22.41 \mathrm{~L} \mathrm{moL}^{-1}\right) \text {, } \\
& \mathrm{R}=\text { Universal gas constant (83.14 L mbar/Mol.K), } \\
& \mathrm{T}=\text { Absolute temperature }(\mathrm{K}) \text {. }
\end{aligned}
$$

\subsection{Analytical Methods}

The measurements of Total Solids (TS), Volatile Solids (VS), Total Kjeldhal Nitrogen (TKN), Ammonia Nitrogen $\left(\mathrm{NH}_{3}\right)$, volatile suspendedsolid and suspended solid of for characterization of organics waste (food waste and napierpakchong I) and inoculum (cow dung) were conducted according to the procedures outlined in Standard Methods (Hamed and Zhang, 2012). Analyzes of Carbon $(\mathrm{C})$, Nitrogen $(\mathrm{N})$ and Hydrogen $(\mathrm{H})$ for substrate were carried out using $\mathrm{CHNS} / \mathrm{O}$ analyzer. The measurement of $\mathrm{pH}$ was conducted using a $\mathrm{pH}$-meter.

\section{RESULTS}

\subsection{Characteristics of Raw Material}

Temperature plays a critical role in the anaerobic codigestion. The temperature for anaerobic co-digestion of napierpakchonk I, food waste and inoculum cow dung is psyhrophilic temperature $\left(25^{\circ} \mathrm{C}\right)$ and thermophilic temperature $\left(45^{\circ} \mathrm{C}\right)$ for 45 days. Along with temperature, the appropriate balance of nutrients is very important for the anaerobic digestion of napierpakchong I and food waste. The advantage of co-digestion with animal dung is that optimum $\mathrm{C} / \mathrm{N}$ ratios are established without adding chemical and higher methane yield and biogas production are the result.

Napier pakchong I have a low content of nitrogen, which results in relatively high $\mathrm{C} / \mathrm{N}$ ratios and typical $\mathrm{C} / \mathrm{N}$ ratios values of substrate are shown in Table 2 and Fig. 4. The napierpakchong I and food waste used in both digesters (R2 and R4) had a $\mathrm{C} / \mathrm{N}$ ratio of 35 and 16 , respectively. Therefore, the nutrient balance in the digesters is dependent upon the addition of an inoculum (cow dung), which relatively high content of nitrogen and the temperature for digestion. The cow dung used in the digesters had a $\mathrm{C} / \mathrm{N}$ ratio of 24 . The initial mixtures napierpakchong I, food waste and cow dung resulted in an overall $\mathrm{C} / \mathrm{N}$ ratio of 25 in $\mathrm{R} 2$ and $\mathrm{R} 4$. This resulted indicates that the $\mathrm{C} / \mathrm{N}$ ratios for $\mathrm{R} 2$ (for psyhrophilic temperature) and R4 (thermophilic temperature) for is near the optimum range (25-30) (Mijung et al., 2012).

\subsection{Effect of Temperature on Biogas Production and Methane Content}

The measured values of biogas production are shown in Fig. 5 and Table 3. The highest average biogas production was observed to be $70 \mathrm{~L} \mathrm{day}^{-1}$ in $\mathrm{R} 4$, while the biogas production for R3, R2 and R1 were about 52, 35 and $25.9 \mathrm{~L}$ day $^{-1}$, respectively. In particular, effect on temperature it was found that the temperature of the R4, R3, R2 and R1were maximum at 45.3, 44.8, 26.7 and $25.3^{\circ} \mathrm{C}$, respectively. It can also be seen that for the digesters operated at thermophilic temperature, the biogas product increased until about day 16 and then gradually leveled off thereafter (R3 and R4), which was readily biodegradable, whilefor the digesters operated at psyhrophilic temperature the biogas production increased until day 20 and then gradually leveled off (R1), except R2 there are the tend of biogas production similarly of thermophilic temperature condition, which increased until day 16 , due to it had mixtures of napierpakchong I, food waste and cow dung resulted in an overall $\mathrm{C} / \mathrm{N}$ ratio of 25 . This resulted indicates that the $\mathrm{C} / \mathrm{N}$ ratios for $\mathrm{R} 2$ (although operated at psyhrophilic temperature) for is near the optinum range (25-30).

Table 2. Typical carbon to nitrogen ratios $(\mathrm{C} / \mathrm{N})$ for inoculum (Cow Dung), napierpakchong I and food waste

\begin{tabular}{ll}
\hline Substrate & $\begin{array}{l}\text { Carbon to nitrogen } \\
\text { Ratio }(\mathrm{C} / \mathrm{N})\end{array}$ \\
\hline Napier pakchong I & 35 \\
Food waste & 16 \\
Cow dung & 24 \\
Napier pakchong I, & \\
food waste and cow dung & 25 \\
\hline
\end{tabular}




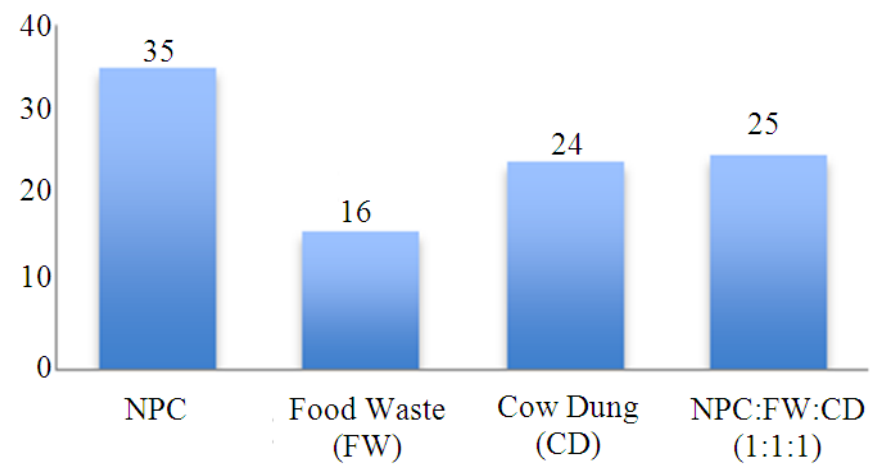

Fig. 4. Carbon to nitrogen ration of Napier Pak Chong I (NPC), Food Waste (FW), Cow Dung (CD) and mixing of Napier Pak Chong 1 (NPC), Food Waste (FW), Cow Dung (CD) (1:1:1)

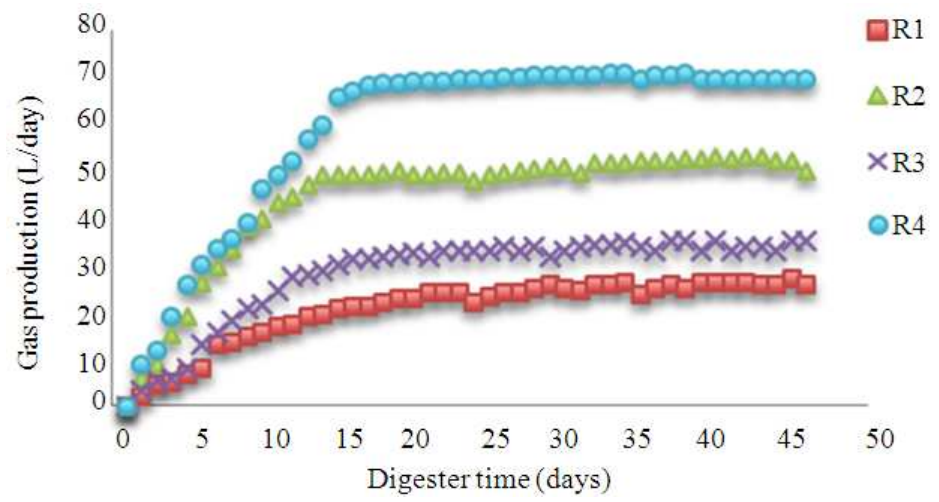

Fig. 5. Gas production obtained in $\mathrm{R} 1$ (food waste $100 \%$ at psyhrophilic temperature $\left(25^{\circ} \mathrm{C}\right)$ ), R2 (co-digestion of napierpakchong I, food waste and cow dung; $1: 1: 1$ at psyhrophilic temperature $\left(25^{\circ} \mathrm{C}\right)$ ), R3 (food waste $100 \%$ at thermophilic temperature $\left.\left(45^{\circ} \mathrm{C}\right)\right)$

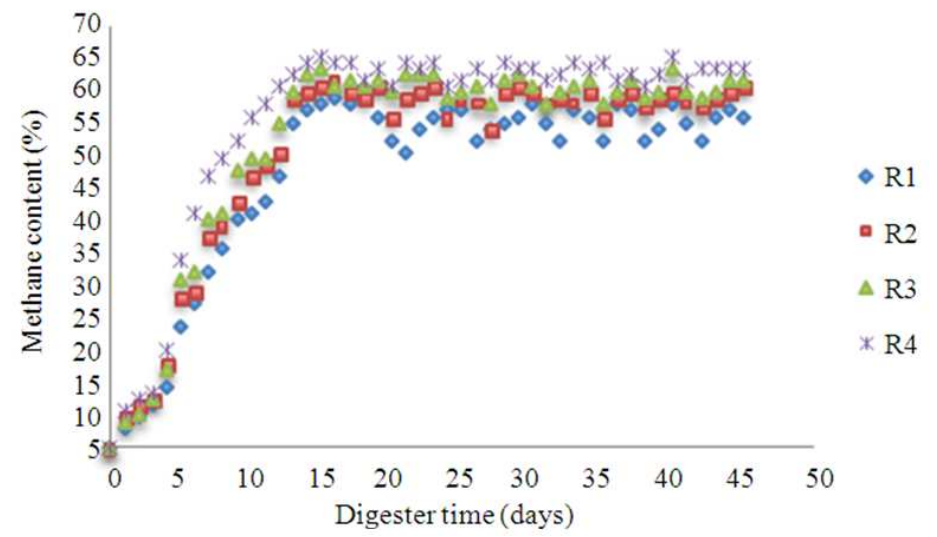

Fig. 6. Methane content obtained in R1 (food waste $100 \%$ at psyhrophilic temperature $\left(25^{\circ} \mathrm{C}\right)$ ), $\mathrm{R} 2$ (co-digestion of napierpakchong I, food waste and cow dung; $1: 1: 1$ at psyhrophilic temperature $\left(25^{\circ} \mathrm{C}\right)$ ), R3 (food waste $100 \%$ at thermophilic temperature $\left.\left(45^{\circ} \mathrm{C}\right)\right)$ 
Several other authors reported an improvement of biogas productivity of anaerobic digesters by supplementing the main substrate with readily digestible co-substrates, which in this research observed that the addition of nepierpakchong I to digestion highest biogas production of R2 (psyhrophilic temperature) and R4 (thermophilic temperature) increased 26 and $28.01 \%$, respectively. To compare highest biogas production of R1 and R3 (same substrate and difference temperature), this substrate were found increased 48.09\%, whilecompare highest biogas production of R2 and R4 (same substrate and difference temperature), this substrate were found increased $49.50 \%$. The reason of biogas production different, which there were similar substrates due to the higher degradability with higher temperature.

The measured values of biogas composition are shown in Fig. 6 and Table 4. Each data point is average of duplicate measurement for each reactor. In terms of Methane $\left(\mathrm{CH}_{4}\right)$ content, the highest methane composition of biogas was $65 \%$ in R4, while R3, R2 and R1 were observed to be 63,61 and $58 \%$, respectively Methane productions as well as VS removal efficiency for the different operating condition.

It is not surprising that the methane production of codigestion system and higher temperature was higher than those of the single digestion system because the OLRs of co-digestion system were set to be approximately equal to the sum of the single system digestion (Panyadee et al., 2013). The highest VS reduction was observed to be 80 , 78, 70 and 68\% for R4, R3, R2 and R1, respectively (Fig. 7). Probably, higher VS conversions might have been achieved for $\mathrm{R} 4$. A C/N ratio 25 seemed to perform better during thermophilic anaerobic co-digestion of napier pak chong I, food waste and cow dung.

Biogas yield of the digestion are shown in Fig. 8. The biogas yield increased $12.5 \%$ of co-digestion system, which compared to thermophilic temperature and psyhrophilic temperature (R4 and R2).

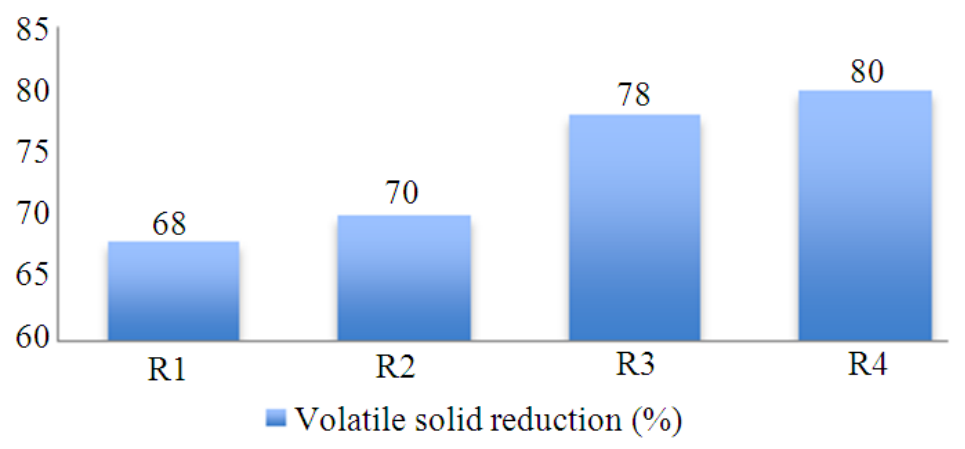

Fig. 7. Volatile solid reduction obtained in R1 (food waste $100 \%$ at psyhrophilic temperature $\left(25^{\circ} \mathrm{C}\right.$ )), $\mathrm{R} 2$ (co-digestion of napierpakchong I, food waste and cow dung; $1: 1: 1$ at psyhrophilic temperature $\left(25^{\circ} \mathrm{C}\right)$ ), R3 (food waste $100 \%$ at thermophilic temperature $\left.\left(45^{\circ} \mathrm{C}\right)\right)$

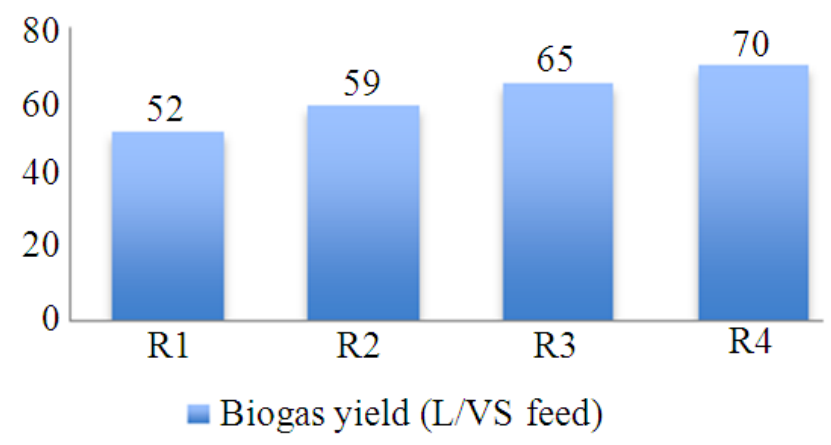

Fig. 8. Biogas yield obtained in R1 (food waste $100 \%$ at psyhrophilic temperature $\left(25^{\circ} \mathrm{C}\right)$ ), R2 (co-digestion of napierpakchong I, food waste and cow dung; $1: 1: 1$ at psyhrophilic temperature $\left(25^{\circ} \mathrm{C}\right)$ ), R3 (food waste $100 \%$ at thermophilic temperature $\left(45^{\circ} \mathrm{C}\right)$ and R4 (co-digestion of napierpakchong I, food waste and cow dung; 1:1:1 at at thermophilic temperature $\left(45^{\circ} \mathrm{C}\right)$ ) 
Lertluck Saitawee et al. / American Journal of Environmental Science 10 (2): 129-139, 2014

Table 3.Gas production in food waste and co-digestion of napier pak chong I, food waste and cow dung under psyhrophilic temperature $\left(25^{\circ} \mathrm{C}\right)$ and thermophilic temperature $\left(45^{\circ} \mathrm{C}\right)$

\begin{tabular}{|c|c|c|c|c|}
\hline \multirow[b]{2}{*}{ Day } & \multicolumn{3}{|c|}{ Gas Production (L/day) } & \multirow[b]{2}{*}{$\mathrm{R} 4$} \\
\hline & $\mathrm{R} 1$ & $\mathrm{R} 3$ & $\mathrm{R} 2$ & \\
\hline 0 & 0.0 & 0.00 & 0 & 0.00 \\
\hline 1 & 2.1 & 5.80 & 3.5 & 8.80 \\
\hline 2 & 4.6 & 8.90 & 5.3 & 11.90 \\
\hline 3 & 5.2 & 15.10 & 5.7 & 18.90 \\
\hline 4 & 6.7 & 18.90 & 8.1 & 25.70 \\
\hline 5 & 8.1 & 26.10 & 13.1 & 29.80 \\
\hline 6 & 13.2 & 29.70 & 15.8 & 33.40 \\
\hline 7 & 13.6 & 33.60 & 18.2 & 35.70 \\
\hline 8 & 14.8 & 38.20 & 20.8 & 39.10 \\
\hline 9 & 15.5 & 39.90 & 21.5 & 46.10 \\
\hline 10 & 16.9 & 43.10 & 24.6 & 48.90 \\
\hline 11 & 17.3 & 44.50 & 27.4 & 51.90 \\
\hline 12 & 19.1 & 46.90 & 28.1 & 56.70 \\
\hline 13 & 19.6 & 48.90 & 28.7 & 59.80 \\
\hline 14 & 20.7 & 49.00 & 29.9 & 65.60 \\
\hline 15 & 21.0 & 49.05 & 31.2 & 67.10 \\
\hline 16 & 21.3 & 49.30 & 31.3 & 68.20 \\
\hline 17 & 21.9 & 49.40 & 31.9 & 68.40 \\
\hline 18 & 22.8 & 49.90 & 32.1 & 68.60 \\
\hline 19 & 23.0 & 49.01 & 32.6 & 69.00 \\
\hline 20 & 23.9 & 49.30 & 31.9 & 69.10 \\
\hline 21 & 23.9 & 49.50 & 32.8 & 69.20 \\
\hline 22 & 24.2 & 49.60 & 32.9 & 69.30 \\
\hline 23 & 21.9 & 47.90 & 32.8 & 69.60 \\
\hline 24 & 23.3 & 48.90 & 33.0 & 69.50 \\
\hline 25 & 23.9 & 49.70 & 33.9 & 69.80 \\
\hline 26 & 24.0 & 50.09 & 33.0 & 70.00 \\
\hline 27 & 24.9 & 50.40 & 33.9 & 70.10 \\
\hline 28 & 25.8 & 50.70 & 31.9 & 70.30 \\
\hline 29 & 24.9 & 50.90 & 32.9 & 70.40 \\
\hline 30 & 24.6 & 49.60 & 33.9 & 70.20 \\
\hline 31 & 25.7 & 51.80 & 34.1 & 70.30 \\
\hline 32 & 25.9 & 51.50 & 34.2 & 70.10 \\
\hline 33 & 26.0 & 51.80 & 34.6 & 70.20 \\
\hline 34 & 23.8 & 51.90 & 33.9 & 69.31 \\
\hline 35 & 24.9 & 52.05 & 32.9 & 70.30 \\
\hline 36 & 25.9 & 52.10 & 35.0 & 70.40 \\
\hline 37 & 24.9 & 52.30 & 34.9 & 70.10 \\
\hline 38 & 26.1 & 52.60 & 33.1 & 69.31 \\
\hline 39 & 26.1 & 52.70 & 34.9 & 69.31 \\
\hline 40 & 26.1 & 52.30 & 32.9 & 69.31 \\
\hline 41 & 26.1 & 52.80 & 33.8 & 69.31 \\
\hline 42 & 25.8 & 52.70 & 33.7 & 69.31 \\
\hline 43 & 25.8 & 51.90 & 33.1 & 69.31 \\
\hline 44 & 26.9 & 52.00 & 34.9 & 69.31 \\
\hline 45 & 25.9 & 49.90 & 35.0 & 69.31 \\
\hline
\end{tabular}

Table 4. Methane production in food waste and co-digestion of napier pak chong I, food waste and cow dung under psyhrophilic temperature $\left(25^{\circ} \mathrm{C}\right)$ and thermophilic temperature $\left(45^{\circ} \mathrm{C}\right)$

\begin{tabular}{|c|c|c|c|c|}
\hline \multirow[b]{2}{*}{ Day } & \multicolumn{4}{|c|}{ Methane Content (\%) } \\
\hline & $\mathrm{R} 1$ & $\mathrm{R} 2$ & R3 & $\mathrm{R} 4$ \\
\hline 0 & 0 & 0 & 0.0 & 0.0 \\
\hline 1 & 3 & 5 & 4.0 & 6.0 \\
\hline 2 & 5 & 7 & 5.5 & 7.9 \\
\hline 3 & 7 & 8 & 8.0 & 9.0 \\
\hline 4 & 10 & 14 & 13.0 & 16.0 \\
\hline 5 & 20 & 25 & 28.0 & 31.0 \\
\hline 6 & 24 & 26 & 29.0 & 39.0 \\
\hline 7 & 29 & 35 & 38.0 & 45.0 \\
\hline 8 & 33 & 37 & 39.0 & 48.0 \\
\hline 9 & 38 & 41 & 46.0 & 51.0 \\
\hline 10 & 39 & 45 & 48.0 & 55.0 \\
\hline 11 & 41 & 47 & 48.0 & 57.0 \\
\hline 12 & 45 & 49 & 54.0 & 60.0 \\
\hline 13 & 54 & 58 & 59.0 & 62.0 \\
\hline 14 & 56 & 59 & 62.0 & 64.0 \\
\hline 15 & 57 & 60 & 63.0 & 65.0 \\
\hline 16 & 58 & 61 & 60.0 & 64.0 \\
\hline 17 & 57 & 59 & 61.0 & 64.0 \\
\hline 18 & 58 & 58 & 60.0 & 61.0 \\
\hline 19 & 55 & 60 & 61.0 & 63.0 \\
\hline 20 & 51 & 55 & 59.0 & 60.0 \\
\hline 21 & 49 & 58 & 62.0 & 64.0 \\
\hline 22 & 53 & 59 & 62.0 & 63.0 \\
\hline 23 & 55 & 60 & 62.0 & 64.0 \\
\hline 24 & 56 & 55 & 58.0 & 60.0 \\
\hline 25 & 56 & 58 & 59.0 & 61.0 \\
\hline 26 & 51 & 57 & 60.0 & 63.0 \\
\hline 27 & 53 & 53 & 57.0 & 61.0 \\
\hline 28 & 54 & 59 & 61.0 & 64.0 \\
\hline 29 & 55 & 60 & 62.0 & 63.0 \\
\hline 30 & 57 & 59 & 60.0 & 63.0 \\
\hline 31 & 54 & 57 & 57.0 & 61.0 \\
\hline 32 & 51 & 58 & 59.0 & 62.0 \\
\hline 33 & 56 & 57 & 60.0 & 64.0 \\
\hline 34 & 55 & 59 & 61.0 & 63.0 \\
\hline 35 & 51 & 55 & 57.0 & 64.0 \\
\hline 36 & 57 & 58 & 59.0 & 61.0 \\
\hline 37 & 56 & 59 & 61.0 & 62.0 \\
\hline 38 & 51 & 56 & 58.0 & 60.0 \\
\hline 39 & 53 & 58 & 59.0 & 62.0 \\
\hline 40 & 57 & 59 & 63.0 & 65.0 \\
\hline 41 & 54 & 57 & 59.0 & 61.0 \\
\hline 42 & 51 & 56 & 58.0 & 63.0 \\
\hline 43 & 55 & 58 & 59.0 & 63.0 \\
\hline 44 & 56 & 59 & 61.0 & 63.0 \\
\hline 45 & 55 & 60 & 61.0 & 63.0 \\
\hline
\end{tabular}


Table 5. Biogas quality parameter

\begin{tabular}{|c|c|c|c|c|c|}
\hline \multirow[b]{2}{*}{ Biogas quality parameter } & \multicolumn{4}{|c|}{ Reporting digester } & \multirow[b]{2}{*}{ Analytical method } \\
\hline & $\mathrm{R} 1$ & $\mathrm{R} 2$ & R3 & R4 & \\
\hline $\mathrm{C} / \mathrm{N}$ ratio & 16.0 & 25.0 & 16.0 & 25.0 & CHNS/O analyzer (Pe2400 SeriesII) \\
\hline Temp. Digester $\left({ }^{\circ} \mathrm{C}\right)$ & 25.3 & 26.7 & 44.8 & 45.3 & Dataloger \\
\hline Biogas yield (L/VS feed) & 52.0 & 59.0 & 65.0 & 70.0 & Portable analyser BIOGAS 5000 \\
\hline$\% \mathrm{CH}_{4}$ (maximize) & 58.0 & 61.0 & 63.0 & 65.0 & \\
\hline Volatile solid reduction $(\%)$ & 68.0 & 70.0 & 78.0 & 80.0 & \\
\hline Maximize biogas product (L/day) & 26.0 & 35.0 & 52.0 & 70.0 & Water Displacement \\
\hline
\end{tabular}

It can also be seen that the lower biogas yield at R1 (digested of food waste at psyhrophilic temperature) indicated there was an inhibition of methaogenic bacteria. Biogas yield were lower when operating under psyhrophilic temperature condition 52 L/VS feed (R1) and $59 \mathrm{~L} / \mathrm{VS}$ feed (R2) compared to $65 \mathrm{~L} / \mathrm{VS}$ feed (R3) and $70 \mathrm{~L} / \mathrm{VS}$ feed (R4), respectively, at thermophilic temperature for single food waste and co-digestion feed of napierpakchong I, food waste and cow dung. This behavior might be due to the higher degradability. From all results, it has been found that the biogas quality parameter in all digester is shown in Table 5.

\section{DISCUSSION}

Even through anaerobic digestion of organic substrates is a well-developed technology, some new technical problems in the anaerobic process occur when new substrates are used. It has been found that codigestion of various material often gives a higher methane production and biogas yield than digestion of a single material. The process of bio-methanation is very sensitive to changes in temperature. The degree of sensitivity, in turn, is dependent on the temperature range. Brief fluctuations not exceeding $\pm 1^{\circ} \mathrm{C} / \mathrm{h}$ may be regarded as still un-inhibitory with respect to the process of fermentation. The temperature fluctuations between day and night are no great problem for plants built underground, since the temperature of the earth below a depth of one meter is practically constant. The graph below indicates the gas production per $\mathrm{kg}$ of substrate in relation to the retention time. The researches indicate that different substrate and different temperatures produce different conditions. In this results, examined the anaerobic digestion of food waste and combined food waste, napierpakchong I and cow dung at psyhrophilic temperature (about 25.3 and $26.7^{\circ} \mathrm{C}$ ) and thermophilic temperature (about 44.8 and $45.3^{\circ} \mathrm{C}$ ), finding that the thermophilic reactor produced higher biogas production, methane content, biogas yield and VS reduction than the psyhrophilic reactor. The results demonstrate that biogas production, methane content and biogas yield are influenced by temperature for single and co-digestion anaerobic digestion. It was found that the suitable raw material ratio ofnapierpakchong 1 , food waste and cow dung for biogas production is $1: 1: 1: 1$. For maximum biogas and methane production and appropriate Carbon to Nitrogen $(\mathrm{C}: \mathrm{N})$ ratio must be followed 25 . There were higher methane content, biogas yield and biogas product along with digester onthermophilic temperature than digester onpsyhrophilic temperature that higher $\% \mathrm{VS}$ reduction, mainly due to high biogas activity. Therefore, the present results in practice suggest that biogas production can be optimized if a digester with thermophilic condition and co digestion can be used effectively as a means of cell and solid material retention within the reactor.

\section{CONCLUSION}

The study reveals that food waste, napierpakchong I and cow dung have a good potential as an energy source in Thailand. The results showed that operating $\mathrm{s}$ continuously reactor at thermophilic temperature condition could optimize the biogas production from codigestion. Napier pakchong I addition to food waste and cow dung digesters improves biogas production on psyhrophilic and thermophilic temperature condition. Best results were obtained when carried out on food waste, napierpakchong I and cow dung on the ratio 1:1:1 atthermophilic temperature condition for 45 days. The increased in biogas production in thermophilicand psyhrophilic temperature condition could be up 28.01 and $26 \%$, respectively, compared to single feed (food waste only and co-digestion). The biogas production from R4 (co-digestion of food waste, napierpakchong I and cow dung $45.3^{\circ} \mathrm{C}$ in 45 days) was found to be 70 
L/day. In addition, temperature was found to influence the methanogenesis and thus digester should be operated at thermophilic temperature condition as which found biogas production, biogas yield and methane content and $\%$ VS reduction higher than at psyhrophilic temperature digester. Therefore, thermophilic digester can be considered a method to improve conversion efficient. However, the extra installation costs and process complexity in control temperature system concept should be evaluated with the economic gain achieved due to extra biogas produced.

\section{ACKNOWLEDGMENT}

Researchers gratefully acknowledge the provision of LC Technologies Limited Partnership and King's Mongkut University of Technology Thonburi.

\section{REFERENCES}

Akbulut, A., 2012. Techno-economic analysis of electricity and heat generation from farm-scale biogas plant: Çiçekdağı case study. Energy, 44: 381390. DOI: 10.1016/j.energy.2012.06.017

Alvarez, R. and G. Lidén, 2009. Low temperature anaerobic digestion of mixtures of llama, cow and sheep manure for improved methane production. Biomass Bioenergy, 33: 527-533. DOI: 10.1016/j.biombioe.2008.08.012

Brown, D. and Y. Li, 2013. Solid stste anaerobic codigestion of yard waste and food waste for biogas production. Bioresource Technol., 127: 275-280. DOI: 10.1016/j.biortech.2012.09.081
Ghaly, A.E. and M.T.A. Hattab, 2011. Effect of diurnally cyclic temperature on the performance of a continuous mix anaerobic digester. Am. J. Biochem. Biotechnol., 7: 146-162. DOI: 10.3844/ajbbsp.2011.146.162

Ghaly, A.E. and M.A. Hattab, 2012. An innovative farm scale biogas/composting facility for a sustainable medium size dairy farm. Am. J. Agric. Biol. Sci., 7: 1-16. DOI: 10.3844/ajabssp.2012.1.16

Hamed, M. and R. Zhang, 2012. Biogas production from co-digestion of dairy manure and food waste. Bioresource Technol., 101: 4021-4028. DOI: 10.1016/j.biortech.2010.01.027

Massé, D.I., G. Talbot and Y. Gibert, 2011. On farm biogas production: A method to reduce GHG emissions and develop more sustainable livestock operations. Anim. Feed Sci. Technol., 166: 436-445. DOI: 10.1016/j.anifeedsci.2011.04.075

Mijung, K., Y. Yingnan, S. Marino, W. Qinghong and V. Michael et al., 2012. Hydrogen production by anaerobic co-digestion of rice straw and sewage sludge. Int. J. Hydrogen Energy, 37: 3142-3149. DOI: 10.1016/j.ijhydene.2011.10.116

Panyadee, A., A. Petiraksakul and C. Phalakornkule, 2013. Biogas production from co-digestion of phyllanthusemblica residues and food waste. Energy Sustainable Dev., 17: 515-520. DOI: 10.1016/j.esd.2013.07.003

Satoto, E., C. Gallert and J. Winter, 2010. Co-digestion of press water and food waste in a biowaste digester for improvement of biogas production. Bioresource Technol., 101: 6987-6993. DOI: 10.1016/j.biortech.2010.03.123 